\title{
Assessing the Social-ecological Resilience of Organic Farmers in Chiang Mai Province, Thailand
}

\author{
Chaiteera Panpakdee ${ }^{1, *}$, Budsara Limnirankul2, Prathanthip Kramol ${ }^{2}$ \\ ${ }^{1}$ Department of Agricultural Extension and System Approaches, Faculty of Agriculture, Khon Kaen \\ University, Khon Kaen, Thailand \\ 2 Department of Agricultural Economics and Agricultural Extension, Faculty of Agriculture, Chiang Mai \\ University, Chiang Mai, Thailand \\ * Corresponding author: chaitpa@kku.ac.th
}

\begin{abstract}
Since resilience is continuing to make its rise to the top of the sustainable development policies, monitoring resilience has become critical because it provides stakeholders with practical actions that can strengthen the state of adaptability to cope with all kinds of change. In this study, resilience, and social theories, such as grounded theory and technography, were integrated as a conceptual framework to produce a specific set of indicators, which yielded forty-seven indices, called social-ecological resilience indicators (SERIs). This study attempts to manage the temporal and spatial scales of resilience systems and to make such indicators suitable for organic rice production systems in four districts of Chiang Mai Province. A questionnaire was utilized to survey fifty-three organic farmers, and the results of the descriptive data analysis indicated that $0.54(1.00=$ the maximum $)$ had been the respondents' average score. Meanwhile, the highest and the lowest scores were serially 0.69 and 0.40 . In addition, the findings revealed that Kendall's Tau-b rank correlation's numeric value came closer to + , which meant that the respondents had demonstrated an average tendency to be resilient. Generally, the highest score of resilience existed for those organic farmers, who had been outstanding in creating opportunities for self-organization, such as considerably relying on food and farm materials from the availability of local resources. Moreover, the majority of them were found to have a secondary on-farm profession that was not only subsidizing additional incomes but was also providing new knowledge and opportunities. This contrasted with the group with lowest score. The farmers, who exhibited unsatisfactory resilience, were centralized in dimensions, ranging from a having a lack of diverse water sources to having sufficient competency to exploit the benefits of Information and Communication Technology (ICT). They are, therefore, more prone to being affected by negative pressures. It is recommended that for building resilience, the 'holy grail' is boosting self-reliance. This capacity is key to reducing the risk of losing sustenance and enabling stakeholders to apply the appropriate strategies in times of change.
\end{abstract}

Keywords: Assessing resilience; building resilience; organic rice; resilience indicators; social-ecological resilience

\section{Introduction}

Since resilience has been described as the magnitude of disturbance that can absorb all kinds of shock and stress and can assist in recovering from them in order to prevent the system from being negatively conversed into a different state with different sets of controls. Since first described, resilience has been predominant in many approaches. This has been especially true in agricultural systems, whose components are abundant and whose operations and tradeoffs are arduous to execute with the command and control approach (Manyena, 2006). The importance of resilience is derived from its core ability to sustain systems, the original domains of function, operations, and mechanisms in the light of dynamic changes (e.g., climate change, pandemics, and economic crises) (Azadi et al., 2011; Folke, 2016). Therefore, for farmers, resilience is vital quality because it provides creative opportunities to achieve sustainable development because every crisis is seen as 'a blessing, instead of a curse' (Panpakdee \& Limnirankul, 2017). However, not all agricultural activities are sufficiently receptive to being resilient. To date, organic farming has been praised as the best field in which to build resilience. The foundation of organic farming promotes adaptive strategies that lead towards autonomy and diversity within an agroecosystem, all of which are irrelevant to conventional farming (Redman, 2014). 
Since the early 1990s, Chiang Mai has been recognized as one of the most important organic rice hubs in Thailand because the province is one of Thailand's attractive and civilized provinces, consisting of an international airport, which is available for exporting products (DOAE, 2013). Also, the province is replete with infrastructure, such as irrigation systems, road networks, agricultural technologies, and niche outlets and convenience stores, all of which are favorable for the achievement of organic rice (ADB, 2017).

Despite receiving various support for over two decades, organic rice farmers in Chiang Mai are still far from reaching their ideal achievements for several reasons. Apart from climate variations, which have been difficult to control, an uncertain demand for organic rice has been their primary area of concern. In general, most organic farmers have tended to sell their output to their cooperative organizations to obtain a better farm price. Occasionally, obtaining a favourable price may not occur right after rice harvest because of difficulties with the cooperative's marketing or internal management. The market and cooperative management constraints have become a disincentive for the organic farmers to maintain the production, especially those marginal farmers, whose financial capacity is too limited, causing them to be unable wait for one to two months to get paid. Regarding the role it plays in promoting organic farming, the government has been criticized for being insincere (Limnirankul \& Gypmantasiri, 2011). Although an enormous budget was reportedly allocated to assist with organic farming, its share was only one percent of the total domestic agricultural budget. Moreover, for the sake of convenience, help, and supervision, local government officers have expected organic farming to be undertaken as a group effort. This means that some forms of agricultural support might not be extended to organic farmers, who run their own individual farms (Green Net, 2013).

According to scholars in agricultural development, resilience is only a workable option against those disturbances. Although the core idea of resilience is described with several meanings, one strand of academic opinion has argued that there are certain definitions in which vulnerability overlaps with resilience. Vulnerability is defined as structural changes in the system, which implies a capacity to preserve the system's structure (Walker \& Cooper, 2011; Folke, 2016). While another considers resilience as the capacity to recover from non-structural changes in dynamics, it notes that resilience treats disturbances in socio-ecological systems as opportunities for learning and doing new things, for establishing innovations, and for furthering development (Carpenter et al., 2001). However, most resilience concepts have one thing in common: the capacity of systems to simultaneously establish the system's adaptive capacity and to decrease vulnerability (Manyena, 2006). Therefore, when farmers, especially those in the least developed countries and in developing countries, whose farming systems have been vulnerable to the dynamic changes of social-ecological systems (SESs), are empowered with resilience, they differ from ordinary farmers because, in terms of their awareness, they recognize that there is no such thing as an ever-stable farming system. Moreover, they have never viewed vulnerabilities as curses, but as opportunities to learn alternative methods with the goal of becoming stronger (Folke, 2016). Consequently, they have been ready to face non-linear agricultural changes, which may not all be desirable, and as a result, have been able to gain new adaptive capacities to assist them in withstanding future uncertainties (Darnhofer, et al., 2016).

Nevertheless, introducing resilience into systems cannot happen overnight and requires timing, alternatives, and from time to time, resources to manage (FAO, 2012). For instance, farmers may lose their resilience in ordinary circumstances if they sell their frequently used farm tools, which are used for on-farm activities. Resilience deterioration is visible as the availability of necessary resources for handling on-farm tasks becomes absent over time (Panpakdee \& Limnirankul, 2017). Conversely, if the farmers are encountering incidences of economic crisis, such selling can be seen as an impromptu adaptation for building resilience. This is because the tractors, which are sold, offer a kind of bounce-forward capacity that enables them to survive a short-term crisis with the goal of achieving longer-term sustainability. Also, on a larger scale, resilience is linked to public policies and social mechanisms (Cabell \& Oelofse, 2012). Resilient farmers can demonstrate a high capacity to cope with shocks and stresses through smart practices (Walker \& Cooper, 2011). However, with such a capacity, farmers might jeopardize themselves if specific inputs, especially if critical infrastructure, such as irrigation and logistics, is funded by them without the government's 
acknowledgment. It is preposterous to expect farmers to invest in those systems that coordinate with the interests of diverse groups of stakeholders, albeit such social-technical systems are sources of institutional resilience (Keele \& Coenen, 2019). Importantly, a series of well-laid plans for stepby-step implementation is also needed since resilience is operational in multi-dimensional contexts, which involve diverse economic, social, and ecological variables (Carpenter et al., 2010). To handle such complexity, finding a framework to monitor the system's resilience is the first effort of those well-laid plans that are aimed at closing the gap between resilience theory and practice (Bene, 2013).

The organic rice farmers in Chiang Mai have been facing both internal and external disturbances (Limnirankul \& Gypmantasiri, 2011; Green Net, 2013). Assessing their resilience is imperative, since it is one of the many ways to enhance production quality and to improve livelihoods for three key reasons (FAO, 2015). Firstly, the outcomes will lead to an understanding of how they have responded and adapted to such disturbances. Secondly, there are tangible outcomes. The existence of outcomes is helpful when the outcomes are utilized as guidelines that enable them to identify flaws, practices, and components (Olsson et al., 2015). This is vital, especially for Thai farmers for whom the majority is marginal. Being aware of what is defective holds the advantage to prioritize which flaw needs to be immediately solved based on their existing resources and cautious consideration. Lastly, quantifying resilience is recognized as a beneficial movement toward withstanding a broad array of natural and human-induced risks (Burton, 2014). By applying a resilience assessment process throughout, the organic farmers can be encouraged to think in terms of considering future uncertainties and multiple feedbacks, including benchmark performance, called resilience degree against best-practice standards. Given that the general nature of human beings has never been designed to satisfy what goes wrong, this can foster a sense competition among peers and can provide opportunities to share knowledge and lessons with one another with the aim of learning how to build resilience using a systematic approach (Sharifi, 2016).

\section{Materials and Methods}

\subsection{The studied areas and sample sizes}

This study was carried out from March to June of 2018 in four districts of Chiang Mai Province (Figure 1), where organic rice production is predominant (Panyakul, 2012). Mae Rim and Mae Taeng are in the northern part, while San Sai and Phrao are in the North-Eastern region of the province.

Because assessing resilience must be "place-based" in order to be relevant to a context's temporal and spatial dimensions (Frazier, 2012), fifty-three organic farmers inhabiting the four districts were selected to provide the data. They were not randomly picked like subjects in other quantitative studies, but were purposefully chosen using snowball sampling to ensure that all informants were small-scale and semi-subsistence farmers, who could represent the majority of Thai farmers (Rigg et al., 2019). Apart from that, two criteria needed to be explored in order to make certain that a satisfactory level of agricultural competence could be secured since these are productive for developing a set of indices called the "social-ecological resilience indicators for organic rice production (SERIs)" through participatory processes (Panpakdee \& Limnirankul, 2017). Firstly, the informants had to have at least five years of experience in organic rice production, and secondly, they had to have passed the transition period into working in an organic rice system.

\subsection{Data collection}

The primary method was the combination of qualitative and quantitative approaches. The literature on SERIs was used as the conceptual framework for developing the questionnaire (Panpakdee \& Limnirankul, 2017). In brief, the SERIs were principally built by semi-structured interviews at the farm level. Initially, to allow the researchers to acquire additional data about the farms, the organic farmers were asked a simple question: "Why do you do organic rice production?" This process generated more constructive questions and discussions. Then, the organic farmers were requested to create the ideal version of a resilient organic rice production system called the 'desirable farm.' The desirable farm had to be coupled with essential components (assets, factors, and resources), which could be used to construct the farm's resilience against dynamic changes. Every component had to be simultaneously built with their evaluative criteria, as well as how to measure them both quantitatively and 
qualitatively (response scales). Moreover, to capture more components, especially adaptation, which has been cited as a critical property for all resilience systems (Kummer et al., 2012), they were also asked a series of questions, which had been strategically designed by the behaviour-based indicators in agroecosystems (Cabell \& Oelofse, 2012), and by scenario analysis, which was based on plausible disturbances (Enfors et al., 2008).

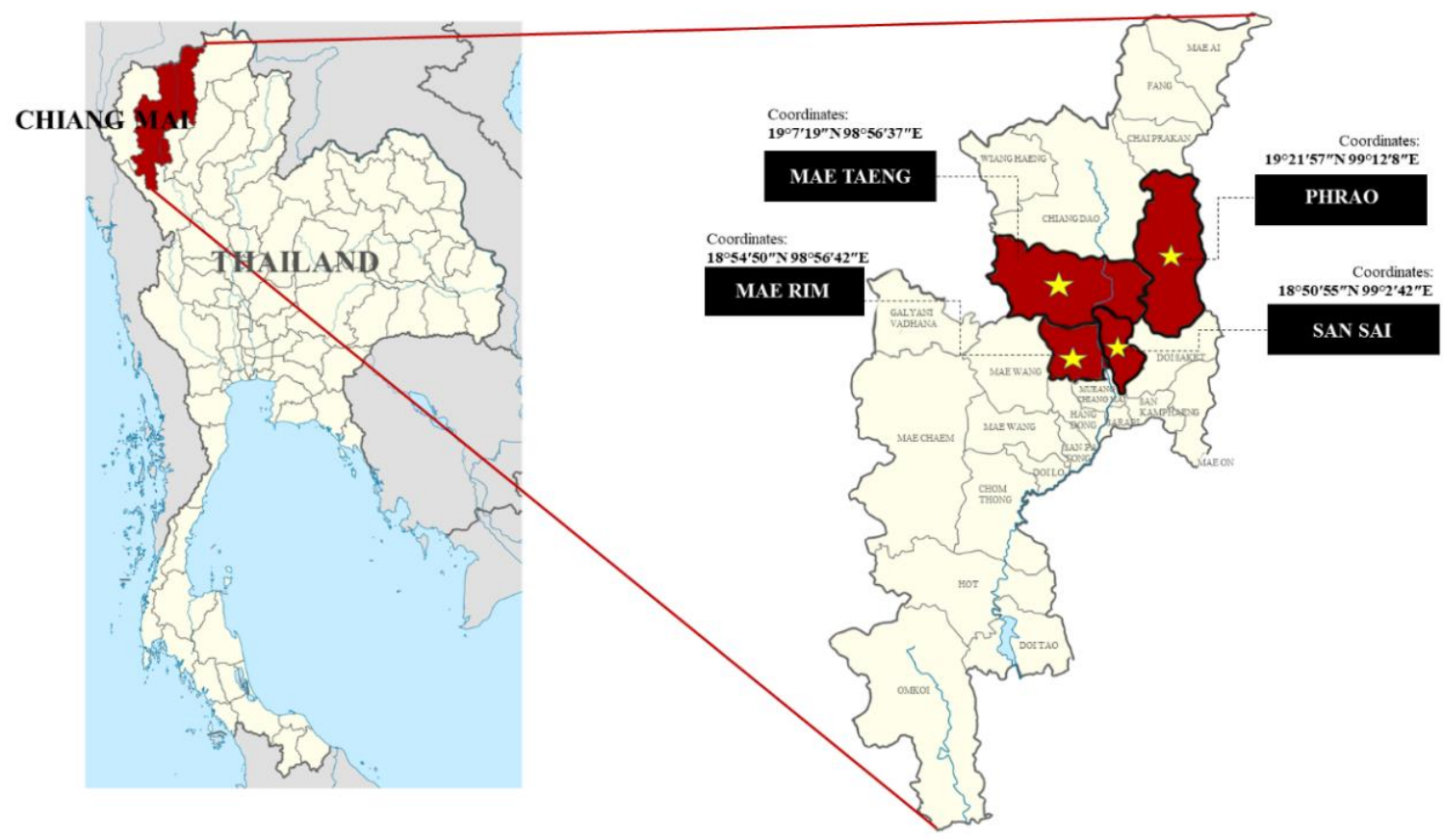

Figure 1. The locations of the studied areas

\subsection{Data analysis}

The interviews were transcribed into descriptive and reflective data with the help of three procedures of qualitative data analysis: (1) data reduction; (2) data display; and (3) conclusions (Miles et al., 2014). Based on the first two processes, both the descriptive and reflective data were examined and assigned into the initial sets of codes, which were displayed as mind maps and which showed the components relevant to the resilience attribute in agroecosystems. Next, the sets of codes were analyzed to screen the complicated data and to aggregate them into classified codes of the same qualifications. In the third procedure, the groups of classified codes, which had already been organized in the same groups of resilient components, were verified and classified with respect to the four vital properties of resilience: (1) learning how to live with change and uncertainty, (2) nurturing various types of ecological, social, and political diversity to increase options and to reduce risks, (3) increasing the range of knowledge for learning and problem-solving, and (4) creating opportunities for selforganization (Folke, 2006). This kind of classification was carried out because during periods of change, outcomes interact across temporal and spatial scales with natural resource dynamics. Moreover, this kind is more appropriate for advising stakeholders about how to operate strategically and methodically in order to achieve resilience (Darnhofer et al., 2016; Folke, 2016).

Next, the organic farmers were asked to assign the scores of the components of resilience by using a single digit number on a fundamental scale ranging from the 1-9 with the aim of approving the computation of the important intensities, which were facilitated by the eigenvector calculation (Saaty, 2008). This was conducted to rank the components from the lowest priority to the highest priority in the aspect of resilience contribution. As a result, forty-seven indices, which were called the socialecological resilience indicators of organic rice production (SERIS), were obtained as follows: 11 SERIs were grouped into the 1st vital resilience property, while the rest contained 10,15, and 11 SERIs, respectively (Table 1 ).

\subsection{Developing a questionnaire based on the SERIS}

Forty-seven SERIs were determined to be fundamental to the goal of developing a questionnaire aimed at gauging resilience. The organic farmers were interviewed using the questionnaire as in other 
quantitative studies. However, before the survey was conducted, Cronbach's alpha coefficient was carried out, and the results yielded an overall reliability of 0.849 . This degree proved that the questionnaire was reliable (Shi et al., 2016). Then, a confirmatory factor analysis was performed to extract the SERIs in order to compute the consistency ratios. The consistency check results for the reliability of the SERIs were in the range of $0.03-0.08$, showing the validity for quantitative evaluation (Tomashevskii, 2015).

\subsection{Calculation of resilience scores}

Given that each SERI had been set with an important intensity to determine its significant level of resilience building, normalization was required (Saaty, 2008). By making every SERI tied in the same column, they were available to be computed as a total score for each vital resilience property (Table 1). According to this study, they were 4 indispensable processes of calculation as follows:

1) The Indicator Normalization Step: The responses to the questions attached to each SERI were first computed as a preliminary score. Next, the score was normalized to re-scale the result to an interval score ranging from 0.0 to 1.0. If more than one question belonged to that SERI, they had to be summed up and then normalized as noted earlier. However, the obtained score was not an outcome because it had to be multiplied with the SERI's important intensity. These processes were done if there was only one SERI paired with the component. If not, the entire process was methodically continued until all SERIs had been computed.

2) The Aggregating Step for Each Component: After all SERIs, attached with the components had been computed, the results were summed to yield the total result, which was multiplied by its component's important intensity. If there was only one component connected to the resilience property, this process was finished. If not, the process continued until every component was computed to produce a result.

3) The Aggregating Step for All Components: After all components of the resilience property had been computed, the results were summed up and were then multiplied with their important intensity. Consequently, one of the four resilience properties was addressed in the summary score.

4) The Aggregating Step for All Properties: The entire process was repeated for the remaining three resilience properties.

As the organic farmers' resilience scores were calculated, they were sorted into four intervals based on the E-S-N-U grading system. This system was selected because it is suitable to reflect their resilient performance and to offer them an incentive for improvement in building resilience, with no numerical data that might otherwise demoralize their confidence (ODI, 2016). 
Table 1. A list of the social-ecological resilience indicators of organic rice production (SERIs) (Panpakdee \& Limnirankul 2017)
Resilience
Components
SERIs
What needed to be considered

Properties

Learning to live

with change

and uncertainty

$(0.25$

\section{Preparing themselves}

for unpredictable

1. Educational level (0.23)

2. Rice farming experience $(0.26)$

3. Occupational skills $(0.28)$

4. Gender equality $(0.23)$

Having reasonable

5. Investments in farm assets $(0.54)$

investments to reduce

risks (0.23)

6. Investments in basic farm equipment (0.48)

Knowing how to use

familiar resources

7. Utilization of ecological services (0.52)

(0.26)

\section{Being open-minded}

and willing to make

8. Additional exploitation of existing water resources $(0.48)$

9. An inquisitive mindset for life-long learning

changes on the farm

$$
\text { (0.35) }
$$

(0.25)

10. An organically-oriented mindset (0.31)

11. Land tenure (0.34)

\begin{tabular}{llll}
\hline $\begin{array}{l}\text { Nurturing } \\
\text { diversity for } \\
\text { reorganiza-tion } \\
\text { and renewal }\end{array}$ & $\begin{array}{l}\text { Diversity of bio- } \\
\text { diversification (0.22) }\end{array}$ & 12. & Diversity of plant species (0.52) \\
\cline { 2 - 4 }$(0.23)$ & $\begin{array}{l}\text { Diversity of economic } \\
\text { opportunities (0.19) }\end{array}$ & $\begin{array}{l}\text { 14. } \\
\text { 15. }\end{array}$ & Diversity of rice varieties for production $(0.48)$ \\
& & & Diversity of marketing channels $(0.26)$
\end{tabular}

$(0.23)$
14. Diversity of income sources $(0.26)$
15. Diversity of marketing channels $(0.26)$

16. Ownership of guaranteed price and organic certification (0.25)

17. Honorific addresses $(0.23)$
- Degree of educational accomplishment

- Number of active years in both organic and conventional rice production

- Number and degree of required skills to accomplish the on-farm tasks

- Degree of female involvement in educational equality and decision-making

- Number of investments in farm equipment and kinds of risk management (e.g., social security insurance and health insurance)

- Number of units of basic farm equipment

- Number and degree of benefits gained from ecological services

- Number of strategies used to exploit greater benefits from existing water resources (e.g. surface and groundwater irrigation)

- Degree of collective action, trust and solidarity in the society, number of accessible social networks for participation and types of media, and the number of household members involved in farming and/or social networks

- The switch to organic rice production must be driven by either health or environmental concerns, not by economic income

- Percentage of land use holding

- Number and variety of planted crops (e.g., food crops, herb, firewood, construction timber, natural insecticide crops, and the degree of important plant protection)

- Number of planted rice varieties

- Number of income sources considering both on and off the farm

- Number and type of accessible markets, and the distance between the farm and key markets within the province

- Ownership of guaranteed price and organic certification

- Number and type of honorific addresses given from institutions 


\begin{tabular}{|c|c|c|c|c|}
\hline & $\begin{array}{l}\text { Diversity } \\
\text { of resources }(0.21)\end{array}$ & $\begin{array}{l}18 . \\
19 .\end{array}$ & $\begin{array}{l}\text { Diversity of water resources }(0.57) \\
\text { Diversity of credit sources }(0.43)\end{array}$ & $\begin{array}{l}\text { - Number and degree of usable water resources } \\
\text { - Number with accessibly legal credit sources, and number with debt independence from } \\
\text { those legal credit sources }\end{array}$ \\
\hline & $\begin{array}{l}\text { Diversity of } \\
\text { information sources } \\
(0.20)\end{array}$ & 20. & Diversity of information sources $(0.20)$ & - Number and degree of accessible information sources $(0.20)$ \\
\hline & $\begin{array}{l}\text { Diversity of partners } \\
\text { and relationship types } \\
(0.18)\end{array}$ & 21. & Diversity of collaborative networks $(0.18)$ & $\begin{array}{l}\text { - Number, type, and degree of collaborative networks (e.g., non-affiliated network } \\
\text { (neighbors and fellow farmers)); commodity consumer networks; governmental } \\
\text { networks and university-based networks (0.18) }\end{array}$ \\
\hline \multirow[t]{13}{*}{$\begin{array}{l}\text { Combining } \\
\text { different types } \\
\text { of knowledge } \\
\text { for learning }\end{array}$} & $\begin{array}{l}\text { Acquiring knowledge } \\
\text { from science and } \\
\text { indigenous knowledge } \\
(0.22)\end{array}$ & $\begin{array}{l}22 . \\
23 . \\
24 .\end{array}$ & $\begin{array}{l}\text { Knowledge designed from a bottom-up approach (0.36) } \\
\text { Heritage of indigenous knowledge }(0.35) \\
\text { Existence of dialects and local traditions }(0.29)\end{array}$ & $\begin{array}{l}\text { - Number and degree of courses designed by locals } \\
\text { - Degree of documentation and transmission of indigenous knowledge }\end{array}$ \\
\hline & & & & $\begin{array}{l}\text { - Degree of speaking the local dialect to others, and the degree of maintaining local } \\
\text { traditions }\end{array}$ \\
\hline & $\begin{array}{l}\text { Obtaining knowledge } \\
\text { from self-effort (0.22) }\end{array}$ & 25. & A variety of learning approaches $(0.35)$ & $\begin{array}{l}\text { - Number and degree of educational platforms for learning (e.g., self-study and } \\
\text { experiments, workshops, and on-farm trials) }\end{array}$ \\
\hline & & 26. & $\begin{array}{l}\text { Obtaining knowledge through the second form of } \\
\text { agricultural employment (0.33) }\end{array}$ & $\begin{array}{l}\text { - Ownership of a secondary agricultural employment, and the number of benefits gained } \\
\text { from that employment }\end{array}$ \\
\hline & & 27. & $\begin{array}{l}\text { Effectively using Information and Communications } \\
\text { Technology (ICT) (0.32) }\end{array}$ & \\
\hline & & & & $\begin{array}{l}\text { - Degree of accessibility to ICT, and the number of benefits gained from the ICT (e.g., time } \\
\text { economy, more access to resources, information, and knowledge) }\end{array}$ \\
\hline & $\begin{array}{l}\text { Adaptive capacities } \\
(0.22)\end{array}$ & 28. & Adaptation (0.18) & $\begin{array}{l}\text { - Number of introduced adaptations to the farm, and degree of shocks and stresses solved } \\
\text { by the adaptations }\end{array}$ \\
\hline & & 29. & Value-added products $(0.20)$ & - Number of processed rice products \\
\hline & & 30. & $\begin{array}{l}\text { Organizing financial flows with the household account } \\
(0.22)\end{array}$ & $\begin{array}{l}\text { - Degree of recording household account/number of using the household account data for } \\
\text { making significant decisions about on-farm activities }\end{array}$ \\
\hline & & 31. & Having a reasonable farm scale $(0.21)$ & - The effective ratio between land used and amount of household labor \\
\hline & & 32. & Securing consumer confidence $(0.19)$ & $\begin{array}{l}\text { - Number of strategies conducted for building loyal consumers (e.g., face-to-face } \\
\text { interaction, holding organic rice fair, and public relations through printed media and } \\
\text { labeling) }\end{array}$ \\
\hline & $\begin{array}{l}\text { Time availability for } \\
\text { learning }(0.16)\end{array}$ & $\begin{array}{l}33 . \\
34 .\end{array}$ & $\begin{array}{l}\text { Being a full-time farmer }(0.51) \\
\text { Marital status and the independence of children (0.49) }\end{array}$ & $\begin{array}{l}\text { - Having or not having off-farm employment } \\
\text { - Having or not having a spouse, who can support farm activities, and having or not having } \\
\text { children, who cannot take care of themselves in the household }\end{array}$ \\
\hline & Living in an & 35. & Number of farming generations $(0.47)$ & - Number of household ancestors, who have produced rice \\
\hline
\end{tabular}




\begin{tabular}{|c|c|c|c|c|}
\hline & $\begin{array}{l}\text { environment that is } \\
\text { favorable for learning } \\
(0.18)\end{array}$ & 36. & Number of neighboring organic farmers $(0.53)$ & $\begin{array}{l}\text { - Number of organic farmers in the community, and number of local farmers, who can } \\
\text { share know-how and teach techniques }\end{array}$ \\
\hline \multirow[t]{3}{*}{$\begin{array}{l}\text { Creating } \\
\text { opportuni-ties } \\
\text { for self- } \\
\text { organization } \\
\text { and cross-scale } \\
\text { linkages }\end{array}$} & $\begin{array}{l}\text { Farm level: } \\
\text { Depending on the } \\
\text { available resources } \\
(0.40)\end{array}$ & $\begin{array}{l}37 . \\
38 . \\
39 . \\
40 .\end{array}$ & $\begin{array}{l}\text { Dependence on household resources }(0.22) \\
\text { Self-rice seed production }(0.20) \\
\text { Dependence on self-produced rice and dietary materials } \\
(0.21) \\
\text { Dependence on household labor }(0.19) \\
\text { Rice field location }(0.18)\end{array}$ & $\begin{array}{l}\text { - Being dependent or not being dependent on self-rice seed production } \\
\text { - Degree of dependence on self-production of rice and dietary materials consumed by the } \\
\text { household } \\
\text { - Percentage of household labor used for the on-farm activities } \\
\text { - Degree of exposure to the rice fields, which is caused by nearby chemicals and the non- } \\
\text { agricultural sector }\end{array}$ \\
\hline & $\begin{array}{l}\text { Community level: } \\
\text { Co-usage of livelihood } \\
\text { assets }(0.27)\end{array}$ & $\begin{array}{l}43 . \\
44 . \\
45 . \\
46 .\end{array}$ & $\begin{array}{l}\text { Cooperative farming }(0.20) \\
\text { Knowledge exchange through networks }(0.22) \\
\text { Dependence on local inputs }(0.21) \\
\text { Dependence on local food systems }(0.19) \\
\text { Mutual labor exchange }(0.18)\end{array}$ & $\begin{array}{l}\text { - Type of help received from collaborating with networks (e.g., having bargaining power } \\
\text { and avoiding economic pressures) } \\
\text { - Number of accessible networks from which to receive knowledge exchange and the } \\
\text { - degree of knowledge efficiently learned through the networks } \\
\text { - Degree of using productive inputs that are either sold or produced at the local level } \\
\text { - Degree of locally sourced food consumed within the household } \\
\text { - Degree of using the exchange of mutual labor to produce organic rice }\end{array}$ \\
\hline & $\begin{array}{l}\text { Cross-scale level: } \\
\text { Opening networks with } \\
\text { the government }(0.33)\end{array}$ & 47. & Favorable support from the government $(0.33)$ & $\begin{array}{l}\text { - Degree of satisfaction with central and local government support in the required aspects } \\
\text { of producing organic rice }\end{array}$ \\
\hline
\end{tabular}

Note: The numbers in parentheses represent the important intensity of each of the SERI's. 


\subsection{Prediction of the resilience possibility}

The data from the questionnaire survey was computed by using the Statistical Package of the Social Sciences software (SPSS) to determine the descriptive statistics and Kendall's Tau-b rank correlation. Kendall's Tau-b rank correlation is a non-parametric measure and was purposefully selected because this study required a statistical method to quantify how strongly any two variables were related and how they were associated with the number of concordances and discordances in tied ranks; the full rating of resilience scores and the actual resilience scores were owned by the small sample size (Zhang et al., 2020). The full rating of resilience scores represented the highest level of SERIs, which had been assigned by the organic farmers. Given that resilience can represent both desirable and undesirable conditions, it was, therefore, imperative to allow them to determine which of the SERIs had been more or less significant in building the resilience of their production system for growing organic rice. Meanwhile, the actual resilience scores were the organic farmers' raw scores, which were given by a summary of the existing resilience performances (Darnhofer et al., 2010).

Kendall's Tau-b rank correlation was run to compare the full-rating for each resilience score in each SERI with the organic farmers' actual resilience score with the goal of estimating their probability of resilience (Ciftcioglu, 2017). Next, one by one, the resilience scores for each of the actual SERIs was calculated to get a percentage. This process was conducted with the aim of obtaining two key outcomes. The first outcome was to describe how the magnitude that had been the actual resilience score was related to its full rating of resilience score. The second was to provide such descriptions of the practical strategies needed. If there was an existing value for the SERIs, which was close to $100 \%$, it signified that these components were considerably available (Chen \& Popovich, 2002; Rafiaani et al., 2020). Conversely, the smaller values showed that these SERIs should be improved to strengthen the organic rice production system in order to cope with all kinds of change (Cabell \& Oelofse, 2012).

\section{Results and Discussions}

According to the results (Table 2), most of the organic farmers were male (62.26\%), and their ages, on average, were approximately 57 years old. Due to the uncertain flow of money and the physical nature of the tasks required for farming, younger generations are not ardent to work in agriculture, which results in a most unpleasant situation for Thailand's food security (Vidyarthi et al., 2009). Regarding experience, which has been cited as being vital to the success of coping and adopting adaptive strategies (FAO, 2015), most of the organic farmers, who participated in the study, had an average of between 6-10 years of experience (20 people; $37.74 \%$ ). This was followed by a group, who had one to five years of experience (28.30\%). Albeit, Thailand has devised policies, which have placed emphasis on organic rice production since 1994. The state of having 6-10 years of experience was first due to the uncertainty of the socio-technical landscapes in the country. For example, it has been difficult for organic farmers to gain access to the larger scale niche markets given that the governments' dominant policies have relied on the regimen of growing conventional rice due to the inherent production of organic farming (Kerdnoi et al., 2014).

Table 2. The organic farmers' socio-economic profiles

\begin{tabular}{lccc}
\hline Contents & & Frequency (no.) & $\%$ \\
\hline 1. Genders & & 33 & 62.26 \\
Male & & 20 & 37.74 \\
Female & Total & $\mathbf{5 3}$ & $\mathbf{1 0 0 . 0 0}$ \\
& & & \\
2. Age (years) & 1 & 1.89 \\
$29-38$ & & 5 & 9.43 \\
$39-48$ & & 13 & 24.53 \\
$49-58$ & & 34 & 64.15 \\
59 and above & Total & $\mathbf{5 3}$ & $\mathbf{1 0 0 . 0 0}$ \\
\hline
\end{tabular}




\begin{tabular}{|c|c|c|}
\hline Contents & Frequency (no.) & $\%$ \\
\hline \multicolumn{3}{|l|}{ 3. Marital status } \\
\hline Single & 1 & 1.89 \\
\hline Married & 50 & 94.34 \\
\hline Widowed & 2 & 3.77 \\
\hline Total & 53 & 100.00 \\
\hline \multicolumn{3}{|l|}{ 4. Educational accomplishments } \\
\hline Primary school & 39 & 73.58 \\
\hline Lower secondary school & 4 & 7.55 \\
\hline Senior high school / Vocational certificate & 7 & 13.21 \\
\hline Higher than senior high school / Vocational & 3 & 5.66 \\
\hline Total & 53 & 100.00 \\
\hline \multicolumn{3}{|l|}{ 5. Number of family members } \\
\hline $1-3$ & 19 & 35.85 \\
\hline $4-6$ & 27 & 50.94 \\
\hline 7 and above & 7 & 13.21 \\
\hline Total & 53 & 100.00 \\
\hline \multicolumn{3}{|l|}{ 6. Years of experience in organic rice production } \\
\hline $1-5$ & 15 & 28.30 \\
\hline $6-10$ & 20 & 37.74 \\
\hline $11-15$ & 8 & 15.10 \\
\hline $15-20$ & 8 & 15.10 \\
\hline$>20$ & 2 & 3.77 \\
\hline Totals & 53 & 100.00 \\
\hline
\end{tabular}

Regarding the agricultural characteristics that existed in the studied areas (Table 3), organic rice production with several organic crops and/or animals in a single system was found to be predominant (86.79\%). Those farmers clearly identified themselves as 'general farmers' rather than considering themselves to solely be organic farmers. Therefore, integrated organic farming production had been selected to complete that purpose and had varied in accordance with each person's objectives. This platform has been favorable for building resilience. Previous studies have highlighted the potential of fostering diverse activities, which can provide financial variability and organic matters, and which are the core of organic rice management (Darnhofer et al., 2010; FAO, 2012). Conversely, mono-crop organic farming has been considerably less cultivated (13.21\%). Organic rice is deliberately cultivated to attain the basic agreement between them and the affiliated contract farming, while conventional rice is planted in a separate area so that it can be consumed by the household. According to the literature (Berkes et al., 2003; FAO, 2015), this can be seen as a measure to provide short-term resilience that can assist in coping with the current situation: receiving a double amount of productivity supplemented by synthetic substances to compensate for their limited household labor (Limnirankul et al., 2010). Nevertheless, it is inhospitable to introduce long-term resilience to pave the way for sustainable agriculture. At one point in time, when some environmental changes occur as a result of their mono crops, their system will, due to the scarcity of diversity, be prone to collapse with regard to its functions and services (Azadi et al., 2011).

Table 3. The organic farmers' agricultural profiles

\begin{tabular}{|c|c|c|c|}
\hline Content & & Frequency (no.) & $\%$ \\
\hline \multicolumn{4}{|l|}{ 1. Integrated organic farming production } \\
\hline Rice-based farming system & & 19 & 35.85 \\
\hline Mixed crop-livestock farming system & & 25 & 47.17 \\
\hline Permaculture & & 2 & 3.77 \\
\hline & Total & 46 & 86.79 \\
\hline
\end{tabular}

2. Mono-crop organic farming production

Rice-based farming system 


\begin{tabular}{|c|c|c|}
\hline Content & Frequency (no.) & $\%$ \\
\hline Rice-based farming, subsequently followed by purposive & 1 & 1.89 \\
\hline crops & 3 & 5.66 \\
\hline \multicolumn{3}{|l|}{$\begin{array}{l}\text { Rice-based farming system grown both organically and } \\
\text { chemically }\end{array}$} \\
\hline Total & 7 & 13.21 \\
\hline
\end{tabular}

Regarding household incomes, the organic farmers had earned an annual income of 13,434,208 THB, which had been subsidized by four main sources: organic rice, vegetables, livestock, and offfarm employment (Table 4). From this table, there are two remarkable matters. Firstly, the organic farmers had had an annual revenue of 253,475.62 THB, which was higher than the ordinary farmers in the country, whose total income had been reported at 210,139 THB (Attavanich et al., 2019). Secondly, most of the excellent farmers, with satisfactory resilience, had shown diversity in their income generation sources (Table 5). In light of this subject matter, it can presumably be interpreted that as compared to other Thai farmers, all organic farmers had tended to be more robust with respect to the dynamic changes of the agroecosystems. This had been due to the higher income (approximately 43,000 THB per year), which had enabled them to foster greater resilience and to invest more in potential tools, such as advisory services, which could assist in reinforcing existing initiatives to manage their business development and risk mitigation (Kummer et al., 2012).

Table 4. The sources of income for organic farmers' in 2017

\begin{tabular}{lc}
\hline Contents & The total amount of annual income (THB) \\
\hline 1. Household incomes & $13,434,208$ \\
Total & 48,000 \\
Minimum & $1,279,700$ \\
Maximum & $253,475.62$ \\
Average per household & \\
\hline 2. Household incomes sorted by activity & \\
Organic rice & $5,663,493$ \\
\hline Total & 16,000 \\
Minimum & 827,700 \\
Maximum & $106,858.36$ \\
Average & $(42.16)$ \\
(\%) & \\
Vegetables and livestock & \\
Total & $3,825,750$ \\
Minimum & 7,332 \\
Maximum & 733,200 \\
Average & $72,183.96$ \\
(\%) & $(28.48)$ \\
Off-farm & \\
Total & \\
Minimum & $3,944,965$ \\
Maximum & 0 \\
Average & 513,000 \\
(\%) & $74,433.30$ \\
\hline & $(29.36)$ \\
\hline &
\end{tabular}

The average resilience score for all the organic farmers had been 0.54 , with 1.00 being the maximum score, while the highest and the lowest resilience scores had been 0.69 and 0.40 , respectively. In regard to the E-S-N-U grading system, the scores were categorized into four intervals. The results showed that there had been twenty-five organic farmers $(47.17 \%)$ with grades of $E$ and $S$, who had been determined to be well-equipped with the abilities to absorb and recover from 
changes. However, for the remainder (52.83\%) with grades of $\mathrm{N}$ and $\mathrm{U}$, it would be necessary for them to strengthen their resilience (Table 5).

Table 5. The resilience scores of the organic farmers and the number and score range for each interval standardized by the E-S-N-U grading system

\begin{tabular}{clcccc}
\hline Intervals & \multicolumn{1}{c}{ Grades } & $\begin{array}{c}\text { Score } \\
\text { ranges }\end{array}$ & $\begin{array}{c}\text { Frequencies } \\
\text { (no.) }\end{array}$ & \% & Means \\
\hline 1 & Excellent resilience (E) & $0.61-0.69$ & 9 & 16.98 & 0.66 \\
2 & Satisfactory resilience (S) & $0.54-0.60$ & 16 & 30.19 & 0.57 \\
3 & Needs improvement of & $0.47-0.53$ & 20 & 37.74 & 0.50 \\
& resilience (N) & & & & \\
4 & Unsatisfactory resilience (U) & $0.40-0.46$ & 8 & 15.10 & 0.43 \\
\hline
\end{tabular}

According to Kendall's tau rank coefficient (Table 6), there had been a significantly moderate positive relationship between the two types of scores at a level of significance of 0.001 (Hinkle et al., 2003). This finding indicated that the organic farmers had exhibited most of the essential components of building resilience in order to cope with all kinds of change. This finding affirms the results from previous studies, which demonstrated that the components of organic farming can promote resilience, which can mitigate the impacts of uncertainty (Milestad \& Hadatsch, 2003; Milestad \& Darnhofer, 2008; FAO, 2013).

As an example, because synthetic inputs are prohibited, most organic farmers are willing to be competent in adaptive strategies, especially those strategies that are associated with how to introduce and enrich the biodiversity of the system. However, this adaptation provides them with only a few benefits. Not only does the nourishment of diversity show the farmers how to manage pests and diseases by utilizing environmentally friendly practices, but it also reveals the benefits of ecosystem services, such as maintaining the soil's sound nutrients, which are the foundation of every robust farm. As a result, when the costs, which are usually spent on manures, are reduced, the farmers have more money left to invest in other resources that can nourish the system's different dimensions and allow the system to become more resilient. With respect to demonstrating how organic rice production can strengthen resilience, this example is only the tip of the iceberg (Muller et al., 2017).

Table 6. The resilience probability of the organic farmers' computed by Kendall's Tau-b

\begin{tabular}{|c|c|c|c|c|}
\hline & & & $\begin{array}{l}\text { Full rating of } \\
\text { resilience score }\end{array}$ & $\begin{array}{l}\text { Actual resilience } \\
\text { scores }\end{array}$ \\
\hline \multirow[t]{6}{*}{ Kendall's tau_b } & \multirow[t]{3}{*}{$\begin{array}{l}\text { Full rating of } \\
\text { resilience score }\end{array}$} & $\begin{array}{l}\text { Correlation } \\
\text { Coefficient }\end{array}$ & 100.0 & $0.518 * *$ \\
\hline & & Sig. (2-tailed) & & 0.0005 \\
\hline & & $\mathrm{N}$ & 47 & 16 \\
\hline & \multirow{3}{*}{$\begin{array}{l}\text { The organic } \\
\text { farmers' actual } \\
\text { resilience score }\end{array}$} & $\begin{array}{l}\text { Correlation } \\
\text { Coefficient }\end{array}$ & $0.518^{* *}$ & 100.0 \\
\hline & & Sig. (2-tailed) & 0.0005 & \\
\hline & & $\mathrm{N}$ & 47 & 16 \\
\hline
\end{tabular}

${ }^{* *}$ Correlation is significant at the level of 0.01 (2-tailed).

Next, the actual resilience scores were investigated to determine which components were their best ten strengths. The results indicated that they had been outstanding in creating opportunities for self-organization and cross-scale linkages given that this vital property had been significant for four out of ten delegates (Table 7). According to the results from the questionnaires, the organic farmers were aware of how to produce production inputs from their household resources. For instance, they knew how to improve the soil nutrients by keeping the rice straw in the organic rice field after the harvest, and then plowing the mulching materials into the soil. Moreover, they had been able to meet their rice and other dietary needs via self-production. Food self-sufficiency positively contributes to resilience building. Compared to ordinary farmers, these farmers had a greater possibility of coping with the difficult pressures, which are caused by Thailand's transition 
economy, because the expenses paid on inputs and food are reduced. In other words, the organic farmers depend primarily on local food and inputs to nourish their food security and activities. Moreover, only the necessary goods, which cannot be produced within the household, are bought from the outside. Such quality is important for building resilience at multiple levels. At the individual level, the organic farming system enables people to consume diverse and better food nutrients and as a result, allows them to be offered the possibility of being free from illness, which is a foundation of building the resilience of the people. At the local level, the commitment to adhere to local food and inputs directly benefits the grass-roots economy since the production and management at the community scale is usually done via a decentralized approach. The producers and consumers are, therefore, less affected by the globalized pressures (Cabell \& Oelofse, 2012).

Three resilience attributes gain benefits from the combination of different knowledge and learning. Apart from being organic farmers, most of them have secondary occupations, which are related to agriculture, such as the occupation of a local soil scientist, who is hired and trained by the Land Development Department. In this situation, they not only are paid for doing the job, but they also acquire supplementary and diverse learning, which helps to improve their resilience strength. Meanwhile, having a reasonable organic farming scale, which favors resilience building, does not exceed the maximum household resource capacity. Otherwise, imprudent land enlargement might lead to diminishing returns. Consequently, a certain amount of time is necessary for the organic farmers to accumulate more knowledge. Continuous learning is vital since it can lead to efficient adaptations to deal with changes. This has been confirmed by Kummer et al. (2012), who indicated that the success of adaptation is the outcome, which is built through dynamic learning and the interconnected interactions of skills, experiences, and strategies.

Also, farming on a reasonable scale can facilitate the quality control of organic rice production. This is vital for the organic farmers because, according to their experiences and the researchers' studies, most of the responsibility for the manual labor is likely born by the organic farmers themselves or by their family members, rather than hired laborers, who are unlikely to work in a dedicated manner for long hours or to work on a wide range of tasks (Milestad \& Darnhofer, 2008).

Utilizing ecological services represents an important learning process that can assist in living with change and uncertainty for resilience building (FAO, 2013). Most organic farmers converted to organic rice production based on the motivation of taking responsibility for environmental stewardship and the quality of the food. This, therefore, inspires them to learn how to apply the available ecological services, which can compensate for the missing soil chemicals, and to receive environmental feedback that can stimulate the ability for self-regulation on the farm. Examples given by the organic farmers during the questionnaire interview included the following: 1) conserving ecosystem patches as habitat to incorporate predators and parasitoids, 2) conducting zero-tillage, and 3) halting the burning of crop residues, which was the previous traditional practice that was used to increase the organic matter in the soil. Moreover, with land tenureship, they have the autonomy to creatively perform these practices, without worrying about yield loss since they legally own the land on which they are currently farming. More importantly, they have more than one source of income, which is understood to be a part of the financial assets of the livelihood assets, which are helpful for building resilience. Having accessibility to secure income sources is indispensable for purchasing a broader range of goods and services during normal periods and during the recovery from periods of shock or stress (Cabell \& Oelofse, 2012). Farmers, who are wealthy, have superior opportunities to own desirable tools and to purchase inputs that protect them from vulnerability (McManus et al., 2012).

Table 7. The ten best strength components of organic farmers, which had contributed to resilience

\begin{tabular}{|c|c|c|c|}
\hline No. & $\begin{array}{l}\text { List of the ten best components of } \\
\text { strength }\end{array}$ & $\begin{array}{c}\text { Type of vital resilience } \\
\text { property }\end{array}$ & $\begin{array}{l}\text { \% From the full } \\
\text { rating }\end{array}$ \\
\hline 1 & Dependence on household resources & 4 & 95.45 \\
\hline 2 & Dependence on local food systems & 4 & 94.74 \\
\hline 3 & A variety of learning approaches & 3 & 94.29 \\
\hline 4 & Utilization of ecological services & 1 & 94.23 \\
\hline 5 & Obtaining knowledge through a second & 3 & 93.94 \\
\hline
\end{tabular}

form of agricultural employment 


\begin{tabular}{clcc}
\hline No. & \multicolumn{1}{c}{$\begin{array}{c}\text { List of the ten best components of } \\
\text { strength }\end{array}$} & $\begin{array}{c}\text { Type of vital resilience } \\
\text { property }\end{array}$ & $\begin{array}{c}\text { \% From the full } \\
\text { rating }\end{array}$ \\
\hline 6 & Diversity of income sources & 2 & 92.31 \\
7 & Land tenure & 1 & 91.18 \\
8.1 & $\begin{array}{l}\text { Dependence on self-produced } \\
\text { rice and dietary materials }\end{array}$ & 4 & 90.48 \\
8.2 & Dependence on local inputs & 4 & 90.48 \\
8.3 & A reasonable farm scale & 3 & 90.48 \\
\hline
\end{tabular}

Table 8 shows the organic farmers' top ten worst components, which can be grouped into two categories to make them easier to understand: (1) the uncontrollable factors and (2) the controllable factors.

The first category is comprised of four components. At the time of the assessment, the organic farmers assigned a score of only 31.58 to their accessibility to diverse water sources for on-farm activities due to occurrences of local drought. When water for farming is severely scarce, they have no chances of using their abilities, such as those that involve triggering waterlogging and floodingbased techniques to exploit greater benefits from those water sources. The organic farmers also assigned a low score to the number of neighboring organic farmers because most of them are living in communities that employ conventional farming techniques. This is both practically and theoretically negative to resilience because the organic farmers are ordinary humans, whose decision-making processes can be shaped or distorted by the influence of their neighboring peers (Limnirankul et al., 2010). To give a simple example, if the organic farmers are mostly surrounded by conventional farmers, they are more likely to be undesirably labeled as 'green farmers.' Consequently, their psychological resilience can easy decay because those 'chemical-using farmers' might want to see them fail (Shava et al., 2010).

Although self-organization is imperative for all resilient systems (Berkes, 2007), it is impossible for farmers to manage their farms in isolation from other segments or organizations, such as various governmental agencies, which are charged with the duty of overseeing public policies and critical infrastructure, such as irrigation systems for flood and drought prevention and mitigation, respectively (FAO, 2012). However, according to the questionnaire survey, the agricultural extension agents have not been seriously facilitating organic rice production. Many extension officers still believe in the positive outcomes and the higher yields of conventional farming. Some organic farmers also stated they had often heard some agricultural extension workers complain about having insufficient budgets to carry out extension activities. Therefore, they had to take risks when spending their limited budgets to purchase inputs to strengthen the farm.

The second category consists of six components. Information and communications technology (ICT) has been playing a key role in agricultural development. This is because ICT and its gadgets can provide farmers with tremendous opportunities to access information, inputs, and data sources about weather forecasts, which are useful in planning the most effective strategies against change (World Bank, 2017). This is especially true for this study, in which most of the organic farmers were subsistence farmers, who desired to improve their livelihoods by utilizing information. However, the organic farmers had been unable to efficiently exploit ICT due to some constraints, such as the locations of their homes, which are in difficult geographic areas, and the tight responsibilities for accessing online services at the most convenient times. However, the biggest challenges were their advanced age, their limited education, and their lack of experience, which hindered them from confidently learning new and complex skills, which are required for using ICT applications.

Two components, which had been recommended for simultaneous enhancement, were having value-added products and investing in farm tools. The production of processed rice products, such as dehydrated rice, bran oil, and pre-germinated rice, are considered to support the process of building resilience because the economic returns can be three to four times higher than those received from selling rice as a raw material (Limnirankul \& Gypmantasiri, 2011; Green Net, 2013). Meanwhile, investing in the required tools for product processing or storage to prevent risk and uncertainty is favorable for resilience building because in times of crisis, such tools can enhance the efficacy of the actions taken to promote resilience (Carmin et al., 2012). 
Finally, to ensure that organic rice production is affordable and within the farmer's capacity, household accounts should be kept, and with respect to incomes, expenses, and debts, the accounts should be used as a reference for planning budgets and making financial decisions (Panpakdee \& Limnirankul, 2017). However, only a few of the organic farmers admitted they knew or had witnessed how to systematically keep household accounting records. Therefore, this component is not only crucial in providing indispensable data for farm management, but also in revealing the weaknesses in the business.

Table 8. The top-ten components of weakness for organic farmers, which had contributed to resilience

\begin{tabular}{clcc}
\hline No & List of the top-ten components of weakness & $\begin{array}{c}\text { Type of vital } \\
\text { resilience properties }\end{array}$ & $\begin{array}{c}\text { \% From the full } \\
\text { rating }\end{array}$ \\
\hline 1 & Effective use of ICT & 3 & 21.88 \\
2 & Diversity of usable water sources & 2 & 31.58 \\
3 & $\begin{array}{l}\text { Additional exploitation of existing water } \\
\text { sources }\end{array}$ & 1 & 52.08 \\
4 & $\begin{array}{l}\text { Favorable support from governmental } \\
\text { institutions }\end{array}$ & 54.55 \\
5 & Investments in farm equipment & 1 & 55.36 \\
6 & Number of neighboring organic farmers & 3 & 60.38 \\
7 & Age and rice-farming experience & 1 & 61.54 \\
8 & Organizing financial flows with the household & 3 & 63.64 \\
& account & & \\
9 & Value-added products & 3 & 65.00 \\
10 & Educational level & 1 & 65.22 \\
\hline
\end{tabular}

\section{Conclusions}

Because the nature of resilience has been dependent on the levels at which phenomena occur both in space and time, vital components, whether greater or lesser, are needed to absorb recurrent disturbances. Moreover, these will be differently influenced by the specific systems that the people inhabit. Therefore, assessing resilience is essential for determining which components (actions, factors, and practices) should be executed to enhance resilience (van Oudenhoven et al., 2010). To make such a process become precise, special features and tradeoffs, which are the drivers of a system and which represent the kinds of shocks that the system needs to cope with, should be conceptualized by the system's owners in order to determine what needs to be assessed and how to best carry out specific evaluations (Ciftcioglu et al., 2017).

Initially, this study was designed to imitate the works cited above for approaching organic rice production, in which change is the rule (ADB, 2017). Therefore, the study was conducted to monitor the resilience scores of selected organic farmers and to identify specific components, which are required to be implemented and are crucial. The outcomes not only specify the challenges and disturbances that farmers encounter, but also the explicit strategies and tradeoffs that must be adopted in order to become resilient (Vroegindewey \& Hodbod, 2018). If these components are not acknowledged, then organic farmers will be unable to efficiently improve their resilient performance because they will be like ships that sail the seas without a compass (Walker \& Cooper, 2011).

The vital resilience properties have never been judged to ascertain which property's influence is superior to the rest in the aspects of building resilience for social-ecological systems (Folke, 2006). Nevertheless, in accordance with this study's results, the components, which are associated with the vital resilience properties of 'learning to live with change and uncertainty' and 'the combination of different knowledge for learning' seem remarkably notable due to two rationales (Kerdnoi et al., 2014). Firstly, the components, which are tied with these two properties, are higher in number than the others (Table 1). Secondly, if the properties' components are examined through a lens of the insights of resilience, they are rooted in how to empower organic farmers to take ownership of specific sets of attitudes, knowledge, and abilities. Consequently, the stakeholders are granted the ability to cope with the unpredictability and the complexity of the world's dynamic contexts, through 
a set of cognitive, emotional, and behavioral reactions (Moss et al., 2008). In other words, they are resilient because they have been able to learn from their cumulative experiences, whether desirable or undesirable, and have been able to adapt and bounce back in times of shock and stress (Burton, 2014).

However, the property of vital resilience, which focuses on nurturing diversity for reorganization and renewal, and focuses on creating opportunities for self-organization and crossscale linkages, cannot be excluded. It is imperative that these properties also be introduced and gradually strengthened since their components are the basic attributes of agricultural sustainability (Miller et al., 2013). As previously mentioned, this is because changes in organic rice production are the norm. Moreover, the components that appear redundant in these properties may someday become significant if social-ecological changes occur (Khanal et al., 2018). Even the components provided by external sources (i.e., relying on local food resources (Table 7) and relying on favorable support from the governmental institutions (Table 8)) are needed for exploitation and reinforcement, respectively. It has been impossible to allow organic farmers to solely build their resilience without these, given that organic rice production is involved with manifold factors that are associated with economic, environmental, political, and social dimensions (Carpenter et al., 2001).

Author contributions: Designing the study, providing a conceptual framework, data analysis: Author 1; revising data analysis, formulating the results: Author 2; revising the writing, improving the conceptual framework and policy recommendations: Author 3; data collection, data analysis, providing the results: Author 4; revising results and policy recommendation: Author 5.

Conflict of interest: The authors declare that they have no competing interests.

Acknowledgment: This study was funded by the Southeast Asian Regional Center for Graduate Study and Research in Agriculture (SEARCA). The authors would like to thank all the organic farmers, who participated at the study sites for their full support.

Ethical statement: The authors declare that this manuscript is original, has not been published before, and is not currently being considered for publication elsewhere. We wish to confirm that there are no known conflicts of interest associated with this publication, and that there has been no significant financial support received for this work, which could have influenced its outcomes. Moreover, we further confirm that the manuscript has been reviewed and approved by all the aforenamed authors. Furthermore, there are no other individuals, who satisfied the criteria of authorship, but were not listed. Lastly, we affirm that each and every aspect of the work, which has been covered in this manuscript, does not contain any studies, which were performed by any of the authors, that have been carried out with human participants or animals.

\section{References}

ADB. (2017). Helping farmers go organic in Thailand. ADB.

Attavanich, W., Chantarat, S., Chenphuengpawn, J., Mahasuweerachai, P., \& Thampanishvong, K. (2019). Farms, Farmers and Farming: A Perspective through Data and Behavioral Insights. PIER Discussion Paper No. 122. Puey Ungphakorn Institute for Economic Research.

Azadi, H., Schoonbeek, S., Mahmoudi, H., Derudder, B., De Maeyer, P., \& Witlox, F. (2011). Organic agriculture and sustainable food production system: main potentials. Agriculture, Ecosystems and Environment, 144 (1), 92-94. https://doi.org/10.1016/j.agee.2011.08.001

Bene, C. (2013). Towards a quantifiable measure of resilience. IDS Working Paper, 434, 1-27. https://doi.org/10.1111/j.2040-0209.2013.00434.x

Berkes, F., Colding, J., \& Folke, C. (2003). Navigating social-ecological systems: building resilience for complexity and change. Cambridge University Press.

Burton, C. G. (2014). A validation of metrics for community resilience to natural hazards and disasters using the recovery from Hurricane Katrina as a case study. Annals of the Association of American Geographers, 105(1), 67-86. https://doi.org/10.1080/00045608.2014.960039

Cabell, J. F., \& Oelofse, M. (2012). An indicator framework for assessing agroecosystem resilience. Ecology and Society, 17(1), 18. http://dx.doi.org/10.5751/ES-04666-170118 
Carmin, J., Nadkami, N., \& Rhie. C. (2012). Progress and challenges in urban climate adaptation planning: Results of a global survey. Massachusetts Institute of Technology.

Carpenter, S., Walker, B., Anderies, J. M., \& Abel, N. (2001). From metaphor to measurement: resilience of what to what? Journal of Ecosystems, 4, 765-781. https://doi.org/10.1007/s10021-001-0045-9

Chen, P. Y., \& Popovich, P. M. (2002). Correlation: Parametric and Nonparametric Measures. Sage Publications.

Ciftcioglu, G. C. (2017). Assessment of the Resilience of Socio-ecological Production Landscapes and Seascapes: A Case Study from Lefke Region of North Cyprus. Ecological Indicators, 73, 128138. https://doi.org/10.1016/j.ecolind.2016.09.036

Darnhofer, I., Fairweather, J., \& Moller, H. (2010). Assessing a farm's sustainability: insights from resilience thinking. International Journal of Agricultural Sustainability, 8, 186-198. https://doi.org/10.3763/ijas.2010.0480

Darnhofer, I., Lamine, C., Strauss, A., \& Navarrete, M. (2016). The resilience of family farms: Towards a relational approach. Journal of Rural Studies, 44, 111-122. http://dx.doi.org/10.1016/j.jrurstud.2016.01.013

DOAE. (2013). Basic agricultural information of Chiang Mai province 2012. DOAE.

Enfors, E. I., Gordon L. J., Peterson G. D., \& Bossio, D. (2008). Making investment in dryland development work: Participatory scenario planning in the Makanya Catchment, Tanzania. Ecology and Society, 13(2), 42. https://doi.org/10.5751/ES-02649-130242

FAO. (2012). Building resilience for adaptation to climate change in the agricultural sector: Proceeding of a joint FAO/OECD Workshop 23-24 April 2012: FAO.

FAO. (2013). Organic agriculture: African experiences in resilience and sustainability. FAO.

FAO. (2015). Increase the resilience of livelihoods to disasters. FAO.

Folke, C. (2006). Resilience: the emergence of a perspective for social-ecological systems analyses. Journal of Global Environmental Change, 16, 53-67. https://doi.org/10.1016/j.gloenvcha.2006.04.002

Folke, C. (2016). Resilience (Republished). Ecology and Society, 21(4), 44. https://doi.org/10.5751/ES-09088-210444

Frazier, T. G. (2012). Selection of scale in vulnerability and resilience assessments. Journal of Geography and Natural Disasters, 2, 3. https://doi.org/10.4172/2167-0587.1000e108

Green Net. 2013. The Situation of Thai Organic Agriculture. Earth Net Foundation and Green Net Cooperative.

Hinkle, D. E., Wiersma, W., \& Jurs, S. G. (2003). Applied statistics for behavioral sciences (5th ed). Houghton Mifflin.

Keele, S., \& Coenen, L. (2019). Policy for critical infrastructure resilience. Arup and Resilience Shift.

Kerdnoi, T., Prabudhanitisarn, S., Sangawongse, S., Prapamontol, T., \& Santasup, C. (2014). The Struggle of Organic Rice in Thailand: A Multi - Level Perspective of Barriers and Opportunities for Up Scaling. Environment and Natural Resources Journal, 12(1), 95-115. https://ph02.tcithaijo.org/index.php/ennrj/article/view/71189

Khanal, U., Wilson, C., Hoang, V. N., \& Lee, B. (2018). Farmers' adaptation to climate change, its determinants and impacts on rice yield in Nepal. Ecological Economics, 144, 139-147. https://doi.org/10.1016/j.ecolecon.2017.08.006

Kummer, S., Milestad, R., Leitgeb, F., \& Vogl, C. (2012). Building resilience through farmers' experiments in organic agriculture: Examples from Eastern Austria. Sustainable Agricultural Research, 1(2), 308-318. https://doi.org/10.1080/23311886.2020.1720555

Limnirankul, B., Gypmantasiri, P., \& Siribut, Y. (2010). Valuing systems of organic agriculture as perceived by smallholder farmers in Northern Thailand. Journal of Agriculture Science, Special issue, 445-448.

Limnirankul, B., \& Gypmantasiri, P. (2011). Agricultural innovation in supporting organic rice production system of smallholder farmers in Northern Thailand. National Science and Technology Development Agency.

Manyena, S. B. (2006). The concept of resilience (Revisited). Disasters, 30(4), 433-50. https://doi.org/10.1111/j.0361-3666.2006.00331.x 
McManus, P., Walmsley, J., Argent, N., Baum, S., Bourke, L., Martin, J., Pritchard, B., \& Sorensen. T. (2012). Rural community and rural resilience: What is important to farmers in keeping their country towns alive? Journal of Rural Studies, 28(1), 20-29. https://doi.org/10.1016/j.jrurstud.2011.09.003

Miles, M. B., Huberman, A. M., \& Saldana, J. (2014). Qualitative Data Analysis (3rd ed.). Sage Publications.

Milestad, R., \& Hadatsch, S. (2003). Organic farming and social-ecological resilience: the Alpine Valleys of Solktaler, Austria. Conservation Ecology, 8(1), 3. http://dx.doi.org/10.5751/ES00584-080103

Milestad, R., \& Darnhofer, I. (2008). Building farm resilience: The prospects and challenges of organic farming. Journal of Sustainable Agriculture, 22(3), 81-97. https://doi.org/10.1300/J064v22n03_09

Miller, C., Saroja, V. N., \& Linder, C. (2013). ICT uses for Inclusive agricultural value chains. FAO.

Moss, D., Waugh, M., \& Barnes, R. (2008). A Tool for Life? Mindfulness as self-help or safe uncertainty. International Journal of Qualitative Studies on Health and Well-being, 3(3), 132142. https://doi.org/10.1080/17482620801939592

Muller, A., Schader, C., El-Hage Scialabba, N. et al. (2017). Strategies for feeding the world more sustainably with organic agriculture. Nature Communications, 8, 1290. https://doi.org/10.1038/s41467-017-01410-w

ODI. (2016). Analysis of Resilience Measurement Framework and Approaches: The Resilience Measurement, Evidence and Learning Community of Practice (CoP). ODI.

Olsson, L., Jerneck, A., Thoren, H., Persson, J., \& O’Byrne, D. (2015). Why resilience is unappealing to social science: theoretical and empirical investigations of the scientific use of resilience. Science Advances, 1(4), 1-11. https://doi.org/10.1126/sciadv.1400217

Panpakdee, C., \& Limnirankul, B. (2017). Indicators for assessing social-ecological resilience: a case study of organic rice production in northern Thailand. Kasetsart Journal of Social Sciences, 39, 414-421. https://doi.org/10.1016/j.kjss.2017.07.003

Panyakul, V. R. (2012). Climate Change Adaptation Through Agro-Social Enterprise: Green Net's Experiences in Thailand. Asian Journal of Environment and Disaster Management, 4(4). http://dx.doi.org/10.3850/S1793924012100092

Rafiaani, P., Dikopoulou, Z., Van Dael, M., Kuppens, T., Azadi, H., Lebailly, \& Van Passel, S. (2020). Identifying Social Indicators for Sustainability Assessment of CCU Technologies: A Modified Multi-criteria Decision Making. Social Indicator Research, 147, 15-44. https://doi.org/10.1007/s11205-019-02154-4

Redman, C. L. (2014). Should sustainability and resilience be combined or remain distinct pursuits? Ecology and Society, 19(2), 37. http://dx.doi.org/10.5751/ES-06390-190237

Rigg, J., Phongsiri, M., Promphakping, B., Salamanca, A. \& Sripun, M. (2019): Who will tend the farm? Interrogating the ageing Asian farmer. The Journal of Peasant Studies, 47(2), 306-325. https://doi.org/10.1080/03066150.2019.1572605

Saaty, T. L. (2008). Relative measurement and its generalization in decision making: Why pairwise comparisons are central in mathematics for the measurement of intangible factors. Statistics and Operations Research, 102(2), 251-318. https://doi.org/10.1007/BF03191825

Sharifi, A. (2016). A critical review of selected tools for assessing community resilience. Ecological Indicators, 69, 629-647. https://doi.org/10.1016/j.ecolind.2016.05.023

Shava, S., Krasny, M. E., Tidball, K. G., \& Zazu, C. (2010). Agricultural knowledge in urban and resettled communities: Applications to social-ecological resilience and environmental education. Environmental Education Research, 16(5-6), 575-589. https://doi.org/10.1080/13504622.2010.505436

Shi, J. H., Liu, L., \& Li, Y. Q. (2016). Reliability and validity of an indicator system for assessing the quality of ophthalmic nursing. Chinese Nursing Research, 3(4), 158-161. https://doi.org/10.1016/j.cnre.2016.11.004

Tomashevskii, I. (2015). Eigenvector ranking method as a measuring tool: Formulas for errors. European Journal of Operational Research, 240, 774-780. http://dx.doi.org/10.1016/j.ejor.2014.07.050 
van Oudenhoven, F., Mijatovic, D., \& Eyzaguirre, P. (2010). Social-ecological indicators of resilience in agrarian and natural landscapes. Management of Environmental Quality, 22(2), 154-173. https://doi.org/10.1108/14777831111113356

Vidyarthi, A., Cadilhon, J. J., \& Hitchcock, D. (2009). Factors affecting conversion from conventional to organic vegetable farming in Thailand. FAO.

Vroegindewey, R., \& Hodbod, J. (2018). Resilience of Agricultural Value Chains in Developing Country Contexts: A Framework and Assessment Approach. Sustainability. 10, 916. https://doi.org/10.3390/su10040916

Walker, J., \& Cooper, M. (2011). Genealogies of resilience: From systems ecology to the political economy of crisis adaptation. Security Dialogue, 42(2), 143-160. https://doi.org/10.1177/0967010611399616

World Bank. (2017). ICT in Agriculture (Updated Edition): Connecting smallholders to knowledge, networks, and institutions. World Bank.

Zhang, L., Lu, D., \& Wang, X. (2020). Measuring and testing interdependence among random vectors based on Spearman's $\rho$ and Kendall's $\tau$. Computational Statistics, 35, 1685-1713. https://doi.org/10.1007/s00180-020-00973-5 